Article

\title{
Substituted 2-Phenacylbenzoxazole Difluoroboranes: Synthesis, Structure and Properties
}

\author{
Agnieszka Skotnicka ${ }^{1, *(1)}$ and Przemysław Czeleń ${ }^{2}$ (1) \\ 1 Faculty of Chemical Technology and Engineering, UTP University of Science and Technology, Seminaryjna 3, \\ 85-326 Bydgoszcz, Poland \\ 2 Department of Physical Chemistry, Collegium Medicum, N. Copernicus University, Kurpińskiego 5, \\ 85-950 Bydgoszcz, Poland; przemekcz@cm.umk.pl \\ * Correspondence: askot@utp.edu.pl; Tel.: +48-(52)-374-9111 \\ Academic Editor: Fawaz Aldabbagh \\ Received: 13 October 2020; Accepted: 18 November 2020; Published: 19 November 2020

\begin{abstract}
Novel fluorescent dyes such as benzoxazole-boron complexes, bearing $\beta$-ketoiminate ligands, have been synthesized and characterized with a focus on the influence of a substituent on the basic photophysical properties. ${ }^{1} \mathrm{H},{ }^{11} \mathrm{~B},{ }^{13} \mathrm{C},{ }^{15} \mathrm{~N}$, and ${ }^{19} \mathrm{~F}$ nuclear magnetic resonance (NMR) spectra of substituted 2-phenacylbenzoxazole difluoroboranes have been recorded and discussed. It is worth mentioning that a high correlation coefficient was found between ${ }^{15} \mathrm{~N}-\mathrm{NMR}$ parameters and substituent constants. The photophysical properties of these new dyes have been investigated by fluorescence and ultraviolet-visible (UV-Vis) absorption spectroscopy. The geometry optimization, vibrational spectra, and the HOMO and LUMO energies were calculated based on density functional theory with the use of the B3LYP functional and 6-311++G(d,p) basis set.
\end{abstract}

Keywords: difluoroboranes; substituent effect; synthesis; spectroscopic properties

\section{Introduction}

Boron dipyrromethene (BODIPY) dyes display excellent photophysical and optoelectronic properties, such as high photostability, a large absorption coefficient in the visible and near-infrared (IR) ranges, excellent chemical stability, high fluorescence quantum yields, relatively long excited-state lifetime, good solubility in organic solvents, relative insensitivity to environmental conditions, and good biocompatibility [1-3]. Moreover, the BODIPY chromophore is a versatile platform for the construction of fluorescent probes for bioimaging and biosensing applications [4-6]. In addition, novel photoinitiators based on the BODIPY are widely used for efficient cationic polymerization of epoxy, epoxy-silicone, and vinyl ether monomers [7,8].

There are mainly three types of these fluorine-boron complexes, classified as $N, N$ bidentate, $O, O$ bidentate, and $\mathrm{N}, \mathrm{O}$ bidentate compounds. The typical BODIPY core contains two pyrrole units and its structure is usually symmetric. The compounds studied now contain $\mathrm{NBF}_{2} \mathrm{O}$ moiety. They carry an unsymmetrically chelated $\mathrm{BF}_{2}$ moiety. It was found that some difluoroboron $\beta$-ketoiminate boron complexes bearing benzoxazole gave strong emissions in solid states on account of aggregation-induced emission (AIE). The reversible mechanofluorochromism was due to the transformation between crystalline and amorphous states [9,10].

In our previous published work, we have investigated the influence of heteroatom $(X=O, S$, and NMe) substitution in a five-membered heterocyclic ring on the photophysical properties of novel $\mathrm{BF}_{2}$ complexes containing or not a dimethylamino group $\left(\mathrm{R}=\mathrm{NMe}_{2}\right)$ [11]. It was shown that the fluorescence yields of the dimethylamino derivatives were much larger (up to one order of magnitude) than those of the corresponding unsubstituted compounds. Therefore, using the electron-donating 
or electron-accepting substituents, the electronic properties of the compounds may be tuned [12,13]. This study provides a report on the basic photophysical properties of a recently synthesized series of substituted 2-phenacylbenzoxazole difluoroboranes (Scheme 1) with a view towards the effect of substitution on their properties.<smiles></smiles>

$$
\mathrm{R}=\text { 4-NMe } 2 \text { (1), 4-OMe (2), 4-Me (3), 3-Me (4), H (5), 3-OMe (6), 4-Cl (7), 3-Cl (8) }
$$

Scheme 1. Structure and atom numbering in 1-8.

\section{Results and Discussion}

\subsection{Synthesis and NMR Data}

Treatment of 2-methylbenzoxazole with benzoyl chloride and triethylamine causes that the 2-methyl group undergoes double benzoylation, i.e., it is transformed to $-\mathrm{CH}=\mathrm{C}(\mathrm{Ph})-\mathrm{COOPh}$. Non purified intermediate products 1a-8a were always used in the subsequent synthetic step. By refluxing their morpholine solutions, 1a-8a can be easily transformed into 2-phenacylbenzoxazoles $\mathbf{1 b}-\mathbf{8 b}$ [14]. In solution, compounds $\mathbf{1 b}-\mathbf{8 b}$ exist in two tautomeric forms, ketimine form $(\mathbf{K})$ and enolimine form $(\mathbf{O})$, through keto-enol tautomerization. The ketimine tautomer structure was confirmed by the methylene signals observed at the range of $4.54-4.67 \mathrm{ppm}(\mathrm{s}, 2 \mathrm{H})$ in their ${ }^{1} \mathrm{H}-\mathrm{NMR}$ spectra. Enolimine tautomers were also confirmed by the ${ }^{1} \mathrm{H}-\mathrm{NMR}$ signals at $6.05-6.43 \mathrm{ppm}(\mathrm{s}, 1 \mathrm{H}, \mathrm{C}=\mathrm{CH})$ and 12.4-12.8 ppm (s, 1H, OH) [15]. The tautomeric mixture $\mathbf{1 b}-\mathbf{8 b}$ was then allowed to react with the boron trifluoride ethyl etherate in the presence of $N$-ethyldiisopropylamine in dichloromethane to give the corresponding $\mathrm{BF}_{2}$ complex 1-8 (Scheme 2).

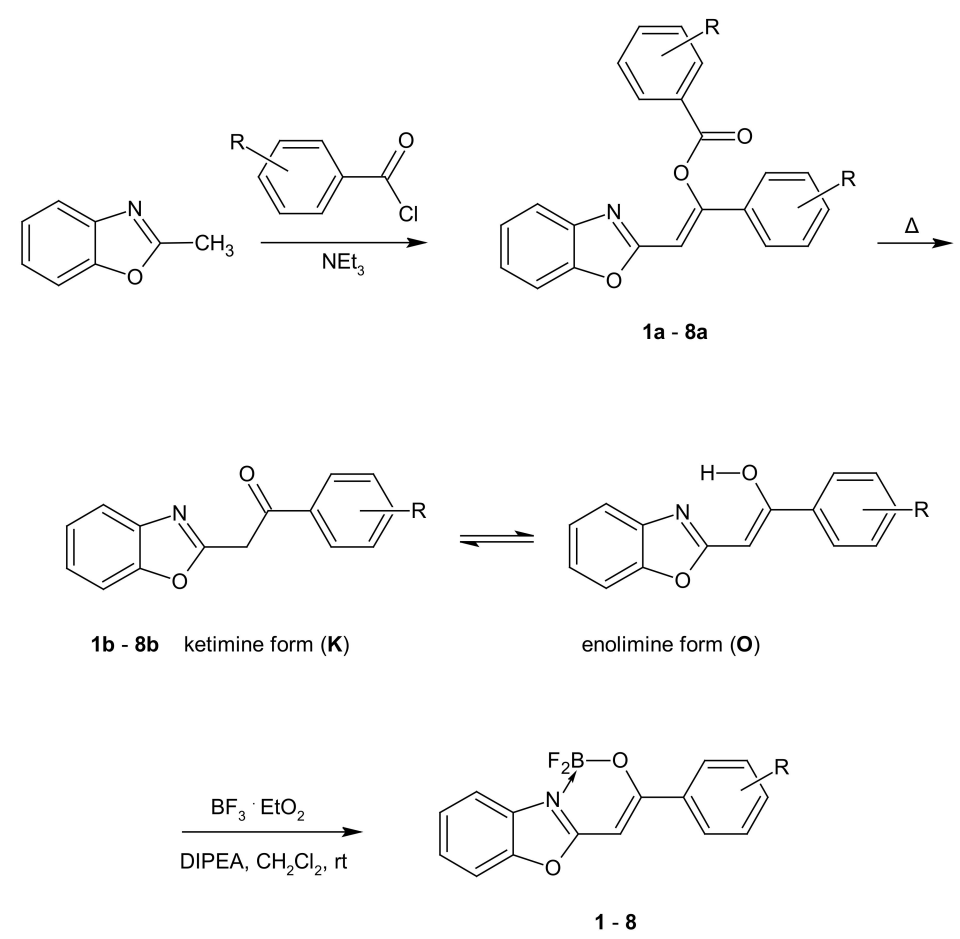

Scheme 2. The schematic representation of the synthesis of 2-phencylbenzoxazole difluoroboranes where $\mathrm{R}=4-\mathrm{NMe}_{2}$ (1), 4-OMe (2), 4-Me (3), 3-Me (4), H (5), 3-OMe (6), 4-Cl (7), 3-Cl (8). 
The ${ }^{1} \mathrm{H},{ }^{11} \mathrm{~B},{ }^{13} \mathrm{C},{ }^{15} \mathrm{~N}$, and ${ }^{19} \mathrm{~F}-\mathrm{NMR}$ spectra that confirm the structures of $\mathbf{1}-\mathbf{8}$ are maintained in solution. NMR chemical shifts of characteristic nuclei are collected in Table 1.

Table 1. Selected ${ }^{1} \mathrm{H},{ }^{11} \mathrm{~B},{ }^{13} \mathrm{C},{ }^{15} \mathrm{~N}$ and ${ }^{19} \mathrm{~F}-\mathrm{NMR}$ chemical shifts of 2-phenacylbenzoxazole difluoroboranes 1-8 for $0.1-0.2 \mathrm{M}$ solution in $\mathrm{CDCl}_{3}$ at $30^{\circ} \mathrm{C}$.

\begin{tabular}{cccccccc}
\hline No. & Substituent & $\mathbf{C 1 0}$ & $\mathbf{C 1 1}$ & H10 & B13 & F13 & N13 \\
\hline $\mathbf{1}$ & 4-NMe 2 & 77.74 & 172.13 & 6.81 & 1.79 & -134.64 & - \\
$\mathbf{2}$ & $4-\mathrm{OMe}$ & 78.85 & 172.23 & 6.37 & 1.80 & -135.59 & -215.72 \\
$\mathbf{3}$ & $4-\mathrm{Me}$ & 79.74 & 172.63 & 6.44 & 1.84 & -135.34 & -215.01 \\
$\mathbf{4}$ & 3-Me & 80.33 & 172.70 & 6.47 & 1.85 & -135.14 & -214.18 \\
$\mathbf{5}$ & $\mathrm{H}$ & 82.11 & 170.79 & 6.49 & 1.85 & -135.07 & -213.54 \\
$\mathbf{6}$ & 3-OMe & 80.56 & 172.28 & 6.47 & 1.84 & -134.98 & -213.97 \\
$\mathbf{7}$ & $4-\mathrm{Cl}$ & 80.63 & 171.01 & 6.45 & 1.81 & -134.98 & -213.00 \\
$\mathbf{8}$ & 3-Cl & 81.17 & 170.64 & 6.48 & 1.81 & -134.78 & -212.43 \\
\hline
\end{tabular}

The ${ }^{1} \mathrm{H}-\mathrm{NMR}$ signal of $\mathrm{H} 10$ of 2-phenacylbenzoxazole difluoroboranes $\mathbf{1}-\mathbf{8}$ can be seen at $\delta=6.37-6.81 \mathrm{ppm}$ in $\mathrm{CDCl}_{3}$, which is a singlet. The presence of a boron atom is confirmed by signals at $\delta=1.79-1.85 \mathrm{ppm}$ (triplet). The resonance of F13 at $\delta=-134.14$ to $-135.59 \mathrm{ppm}$ shows as a quartet (two fluorine atoms). Analogously Kubota et al. [16] observed signals at $-134.6 \mathrm{ppm}$ (q, 2F) for boron complex of 2-methylbenzothiazole. N3 in the ${ }^{15} \mathrm{~N}-\mathrm{NMR}$ spectra of 2-phenacylbenzoxazole difluoroboranes 1-8 resonates in the ranges of $\delta=-212.43$ to $-215.72 \mathrm{ppm}$. These signals were correlated to the Hammett substituent constant $\sigma$ [17]. It was observed that with increasing electron-withdrawing ability of substituent, the ${ }^{15} \mathrm{~N}-\mathrm{NMR}$ signal experienced a continuous upfield shift, which was indicated by a linear dependence of the chemical shift against $\sigma\left(\delta(15 \mathrm{~N})=4.79 \sigma-214.12, \mathrm{R}^{2}=0.909\right)$, Figure 1 . ${ }^{1} \mathrm{H}$ NMR and ${ }^{13} \mathrm{C}$ NMR spectra of 1-8 are available in Supplementary Materials.

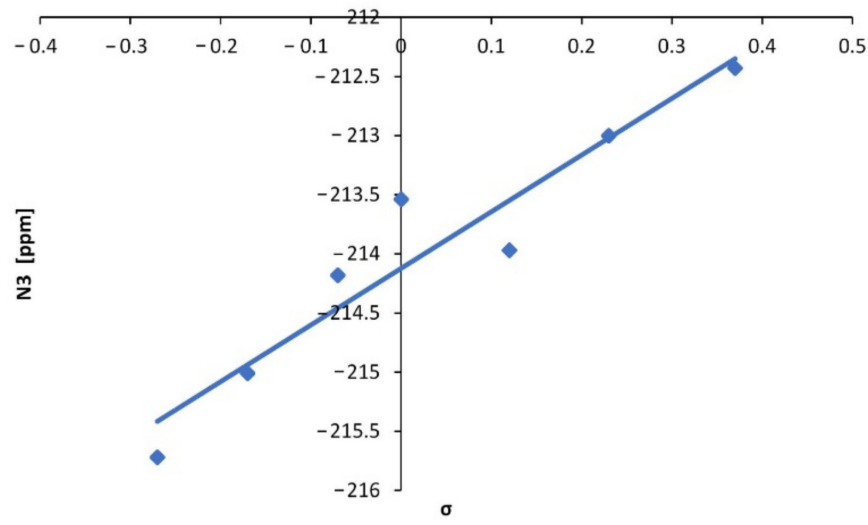

Figure 1. A plot of N3 chemical shift [ppm] vs. Hammett constant for 1-8.

\subsection{Spectroscopic Properties}

The measured absorption spectra of all eight compounds obtained in chloroform are given in Figure 2, and the associated data are presented in Table 2. Chloroform is a known solvent to prevent boron-ligand dissociation, exciplex formation, or the photochemical reactions possible in solvents containing Lewis bases, aromatic rings, or double bonds [18].

As shown in Figure 2, 2-phenacylbenzoxazole difluoroboranes 1-8 have an intense, wide absorption band in the 300-410 $\mathrm{nm}$ region, which is attributed to the $\pi \rightarrow \pi^{*}$ transition but also associated with $\mathrm{n} \rightarrow \pi^{*}$ photochemically forbidden transition. The position of the absorption band depends on the dye structure. Absorption at $\lambda_{\max }$ was found to progressively shift to longer wavelength upon substituting unsubstituted complex 5 by weaker electron-withdrawing $(\mathrm{Cl})$ and then electron-releasing (4-Me, 4-OMe, and 4- $\mathrm{NMe}_{2}$ ) substituents. It must be highlighted that the electron pulling effect from the boron atom created a strong electronic current in the six-membered ring such as B-O-C-C-C-N, 
which is responsible for the higher \% of bathochromic in compound 2 in chloroform. A considerable red-shift of the absorption band was observed for compound 1 (4-NMe 2 ). The 4-NMe $\mathrm{Nubstituent}_{2}$ causes a $58 \mathrm{~nm}$ red shift in absorption relative to the parent compound 5 . The molar absorption coefficient $(\varepsilon)$ of $\mathbf{1}(42,500)$ was significantly higher than for other complexes (Table 2). These red-shifts of the absorption maxima position along with the high molar absorption coefficients indicate that the transitions of the $\mathrm{R}=\mathrm{NMe}_{2}$ derivative have a $\pi \rightarrow \pi^{*}$ nature associated with a significant charge transfer (CT) [11].

The changes in Stokes shifts (Figure 3) and the molar absorption coefficients related to the nature of the substituent in 2-phenacyl moiety are also reflected in changes in the fluorescence quantum yields. As can be seen in Table 2, the measurements of the fluorescence quantum yields of the investigated dyes remain very small. Only derivatives with electron-releasing groups exhibit fluorescence quantum yields significantly higher (up to one order of magnitude for $\mathbf{1}$ ).

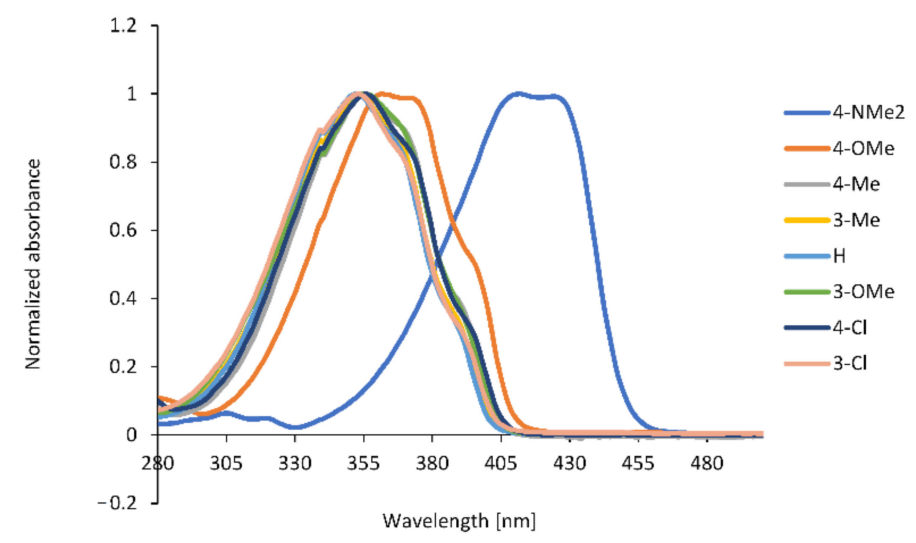

Figure 2. Normalized absorption spectra of 1-8 in chloroform (values were converted to have the maximum normalized at 1 ).

Table 2. Photophysical properties of examined compounds measured in chloroform.

\begin{tabular}{ccccccc}
\hline No. & Substituent & $\begin{array}{c}\boldsymbol{\lambda}_{\text {abs }} \\
(\mathbf{n m})\end{array}$ & $\begin{array}{c}\boldsymbol{\lambda}_{\mathbf{f l}} \\
(\mathbf{n m})\end{array}$ & $\begin{array}{c}\varepsilon \\
\left(\mathbf{M}^{-\mathbf{1}} \cdot \mathbf{c m}^{-\mathbf{1}}\right)\end{array}$ & $\begin{array}{c}\text { Stokes Shift } \\
\left(\mathbf{c m}^{-\mathbf{1}}\right)\end{array}$ & $\begin{array}{c}\boldsymbol{\phi}_{\mathbf{f l}} \\
\left(\times \mathbf{1 0}^{-\mathbf{2}} \mathbf{)}\right.\end{array}$ \\
\hline $\mathbf{1}$ & $4-\mathrm{NMe}_{2}$ & 410 & 458 & 42,500 & 2449 & 98.18 \\
$\mathbf{2}$ & $4-\mathrm{OMe}$ & 362 & 433 & 32,900 & 4530 & 1.82 \\
$\mathbf{3}$ & $4-\mathrm{Me}$ & 354 & 428 & 31,219 & 4884 & 0.66 \\
$\mathbf{4}$ & $3-\mathrm{Me}$ & 352 & 423 & 22,961 & 4769 & 0.48 \\
$\mathbf{5}$ & $\mathrm{H}$ & 350 & 424 & 27,000 & 4905 & 0.54 \\
$\mathbf{6}$ & $3-\mathrm{OMe}$ & 354 & 429 & 26,727 & 4938 & 0.57 \\
$\mathbf{7}$ & $4-\mathrm{Cl}$ & 355 & 428 & 29,615 & 4805 & 0.58 \\
$\mathbf{8}$ & $3-\mathrm{Cl}$ & 353 & 430 & 29,648 & 5073 & 0.50 \\
\hline
\end{tabular}
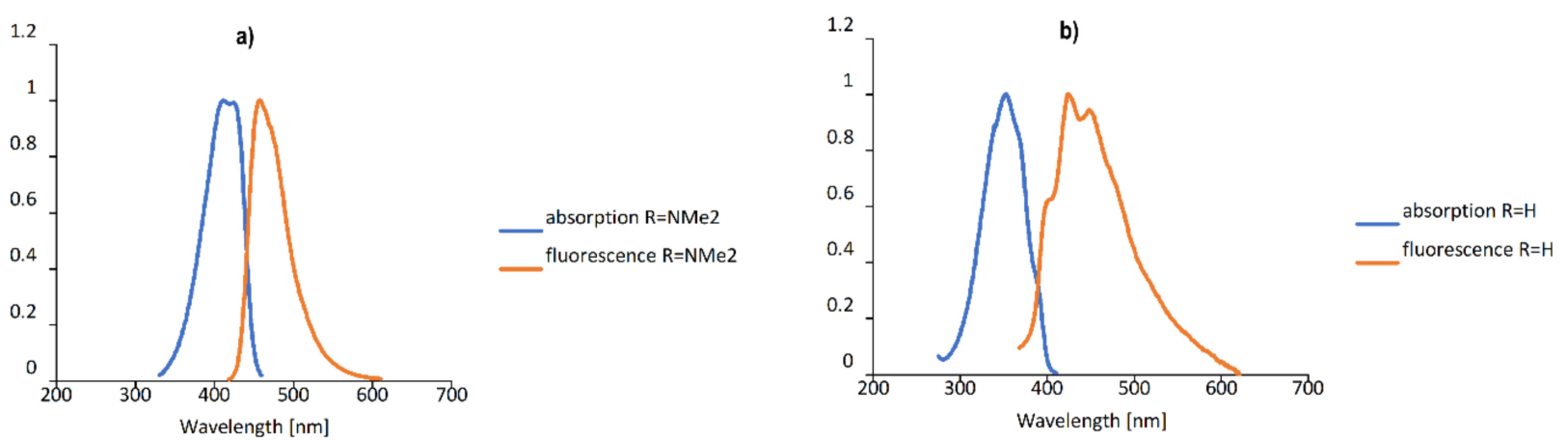

Figure 3. The normalized UV-Vis absorption (a) fluorescence and (b) spectra of $\mathbf{1}$ and $\mathbf{5}$ in $\mathrm{CHCl}_{3}$. 
From the data presented in Table 3 and Figure 4, it is seen that the polar protic solvents such as methanol, dimethylformamide, acetonitryle, and dimethyl sulfoxide cause a bathochromic shift of the absorption band. The largest shift of the absorption bands towards longer wavelengths is observed for the most protic solvent, which is dimethyl sulfoxide. It is clear from Table 3 that the Stokes shift increases with varying solvent polarity. With an increase in solvent polarity, the magnitude of the Stokes shift varies from $2449 \mathrm{~cm}^{-1}$ to $3043 \mathrm{~cm}^{-1}$ for compound $1\left(4-\mathrm{NMe}_{2}\right)$, and from $4530 \mathrm{~cm}^{-1}$ to $6464 \mathrm{~cm}^{-1}$ for other derivatives.

Table 3. Spectroscopic properties of 2-phenacylbenzoxazole difluoroboranes 1-8 in solvents of different polarity.

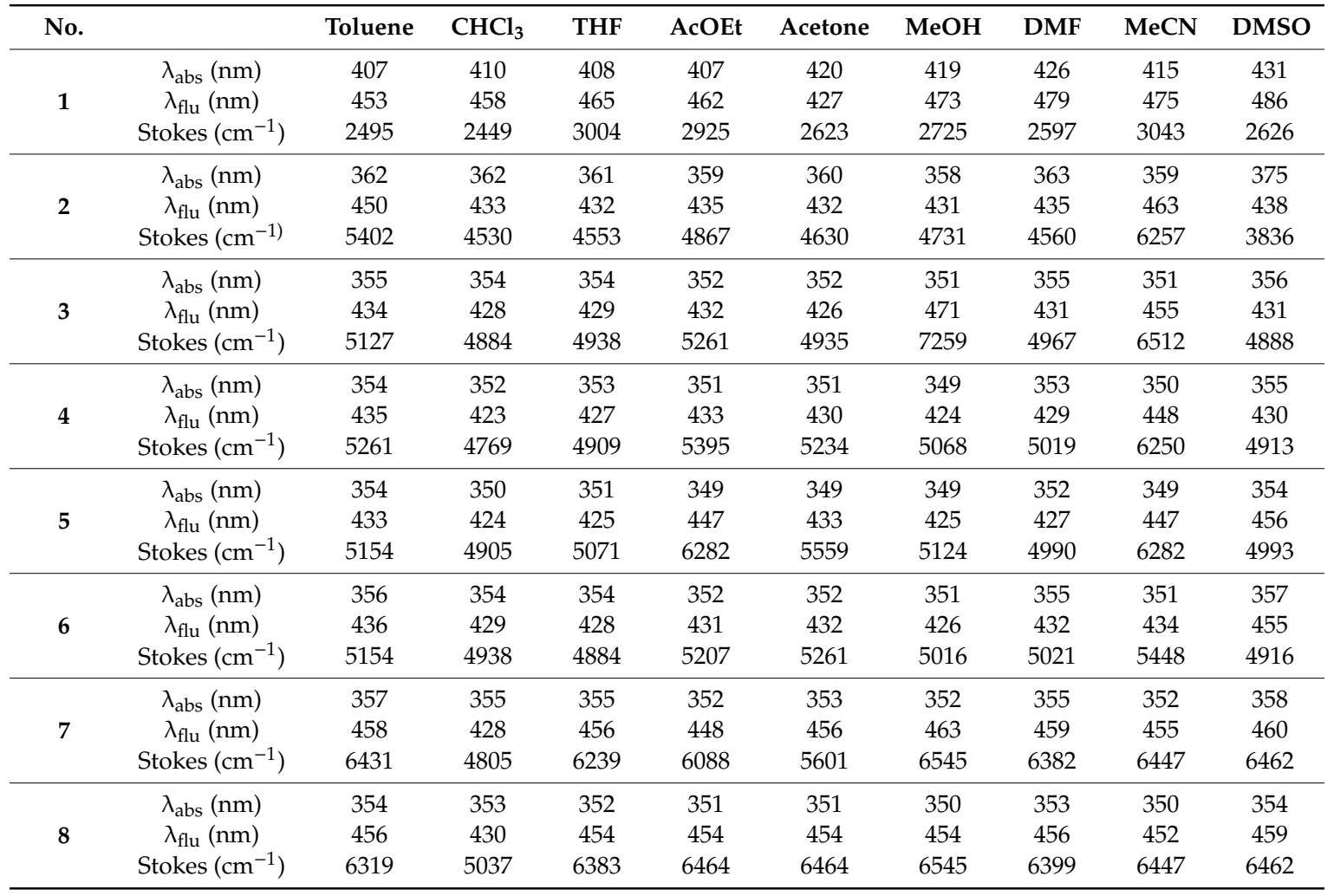
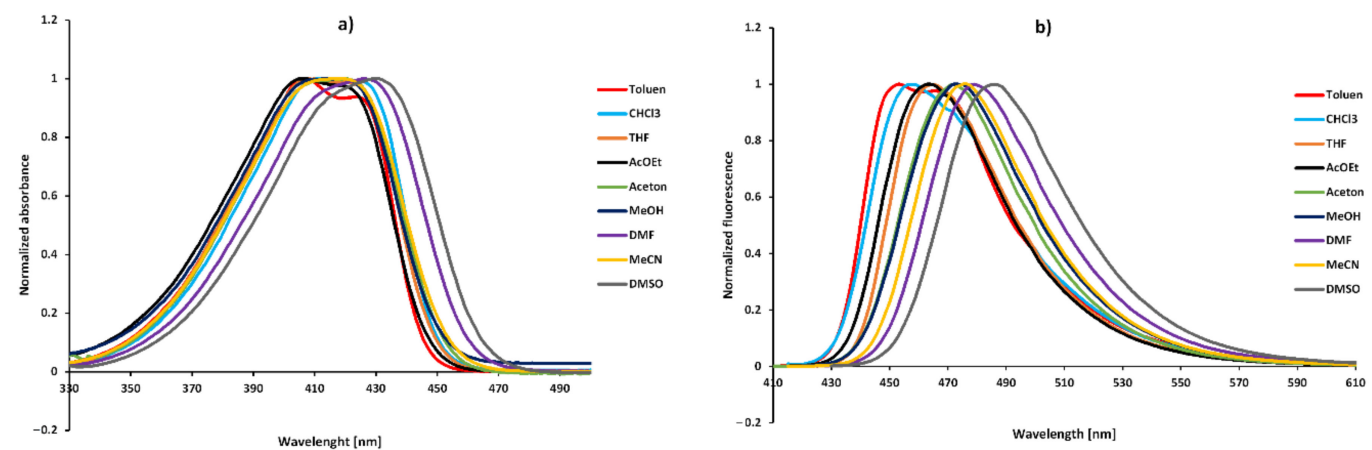

Figure 4. (a) Normalized absorption (a) and fluorescence (b) spectra of 2-(4-dimethylamino)benzoy lbenzoxazole difluoroborane (1) in solvents of different polarity. 


\subsection{Solvatochromism}

To verify the effect of solvent polarity, Stokes shifts $(\Delta v)$ of 1-8 in a variety of solvents were plotted against the solvent polarity parameter $\Delta f(\varepsilon, n)$ with the general form of the Lippert-Mataga equation given below $[19,20]$

$$
\begin{gathered}
\Delta v=\frac{2 \Delta f}{4 \pi \varepsilon_{0} t s h c a^{3}}\left(\mu_{e}-\mu_{g}\right)^{2}+b \\
\Delta f=\frac{\varepsilon-1}{2 \varepsilon+1}-\frac{n^{2}-1}{2 n^{2}+1}
\end{gathered}
$$

in which $\Delta v=v_{a b s}-v_{e m}$ stands for Stokes shift, $v_{a b s}$ and $v_{e m}$ are absorption and emission frequency $\left(\mathrm{cm}^{-1}\right)$, $\hbar$ is the Planck's constant, $c$ is the velocity of light in vacuum, $a$ is the Onsager radius, and $b$ is a constant. $\Delta f$ is the orientation polarizability, $\varepsilon$ is the refractive index, $n$ is the dielectric constant, $\mu_{e}$ and $\mu_{g}$ are the dipole moments of the emissive and ground states, respectively, and $\varepsilon_{0}$ is the permittivity of the vacuum. $\left(\mu_{e}-\mu_{g}\right)^{2}$ is proportional to the slope of the Lippert-Mataga plot.

Lippert-Mataga plots showed higher Stokes shifts for all compounds in acetonitrile as a solvent, nonlinear nature of the plot was observed in acetonitrile for 1-6 shown in Figure 5, while such behavior for $\mathbf{7}$ and $\mathbf{8}$ was observed in chloroform. Compound 7 exhibited similar nature to that of 8 .
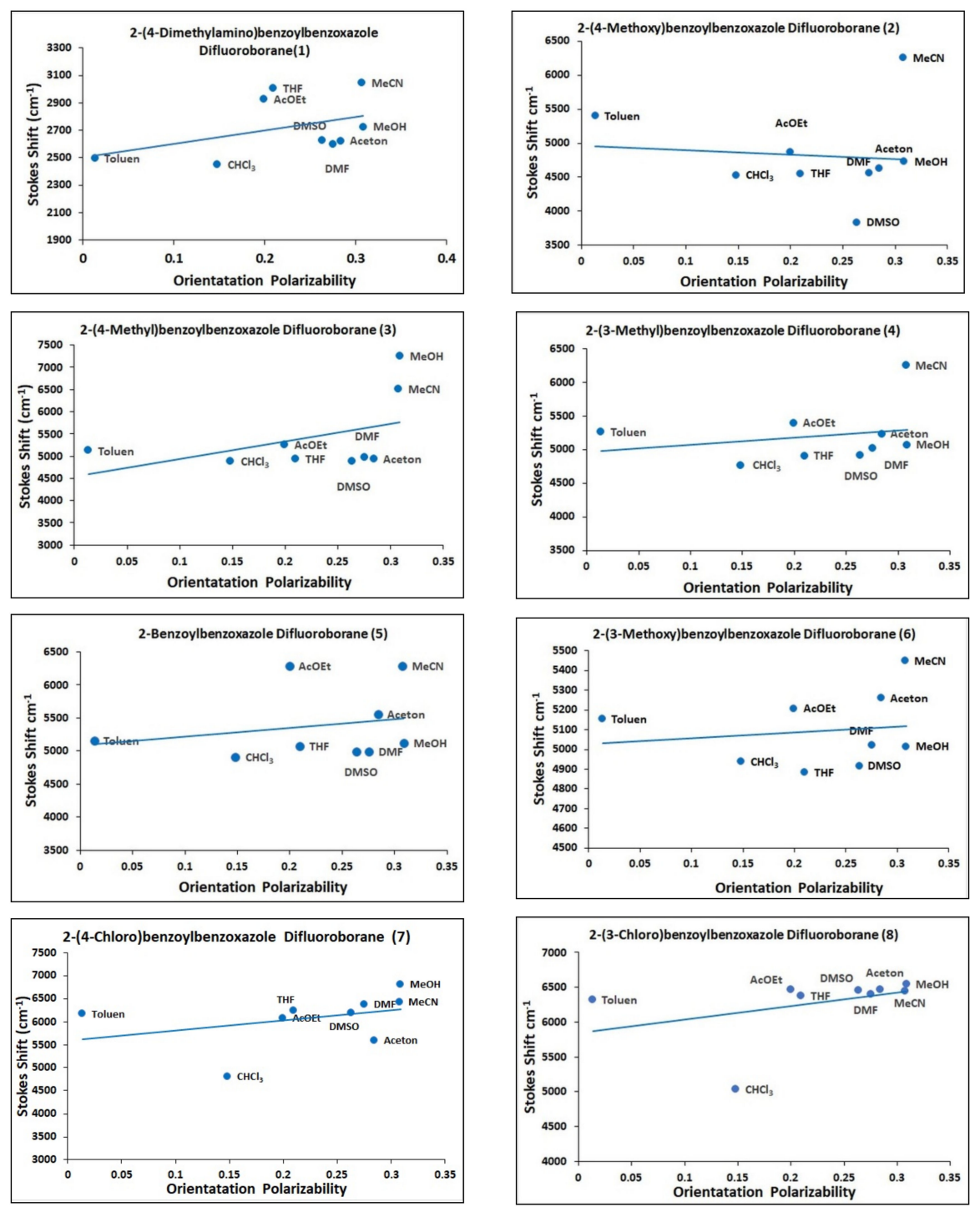

Figure 5. Lippert-Mataga plot of compounds 1-8. 


\subsection{Computational Details}

An important factor in assessing the practical use of the compounds under consideration is their reactivity. The use of computational chemistry methods allows us to describe this property of the tested molecules in the context of a set of descriptors based on the energy values of the frontal orbitals [21]. In Table 4, there are presented values characterizing all considered substituted 2-phenacylbenzoxazole difluoroboranes, including energy values of HOMO and LUMO orbitals, energy gaps, and hardness ( $\eta$ ). Obtained data show that among all considered molecules, the highest reactivity is exhibited by the derivative containing 4-dimethylamino substituent. Such a molecule is characterized by the lowest values of hardness and energy gap. The distribution of HOMO and LUMO orbitals obtained for this molecule is presented in Figure 6. The rest of the considered derivatives exhibit quite similar values of both reactivity descriptors, however, there is observed a trend indicating that substitution in the fourth position to aromatic ring is more favorable than in the third. Taking into account all considered substituents, a decrease in reactivity is observed in the following order 4- $\mathrm{NMe}_{2}>4-\mathrm{OMe}>4-\mathrm{Cl}>4-\mathrm{Me}$ $>3-\mathrm{Cl}>\mathrm{H}>3-\mathrm{Me}>3-\mathrm{OMe}$.

Table 4. The values of hardness ( $\eta$ ), energy gap, and energies of HOMO and LUMO orbitals were estimated for considered molecules.

\begin{tabular}{cccccc}
\hline No. & Substituent & HOMO $(\mathbf{e V})$ & LUMO $(\mathbf{e V})$ & Energy gap $(\mathbf{e V})$ & $\eta(\mathbf{e V})$ \\
\hline $\mathbf{1}$ & $4-\mathrm{NMe}_{2}$ & -5.664 & -2.090 & 3.574 & 1.787 \\
$\mathbf{2}$ & $4-\mathrm{OMe}$ & -6.168 & -2.323 & 3.846 & 1.923 \\
$\mathbf{3}$ & $4-\mathrm{Me}$ & -6.328 & -2.423 & 3.906 & 1.953 \\
$\mathbf{4}$ & $3-\mathrm{Me}$ & -6.389 & -2.454 & 3.935 & 1.967 \\
$\mathbf{5}$ & $\mathrm{H}$ & -9.438 & -2.504 & 3.934 & 1.967 \\
$\mathbf{6}$ & 3-OMe & -6.390 & -2.425 & 3.964 & 1.982 \\
$\mathbf{7}$ & $4-\mathrm{Cl}$ & -6.523 & -2.663 & 3.860 & 1.930 \\
$\mathbf{8}$ & 3-Cl & -6.595 & -2.684 & 3.910 & 1.955 \\
\hline
\end{tabular}

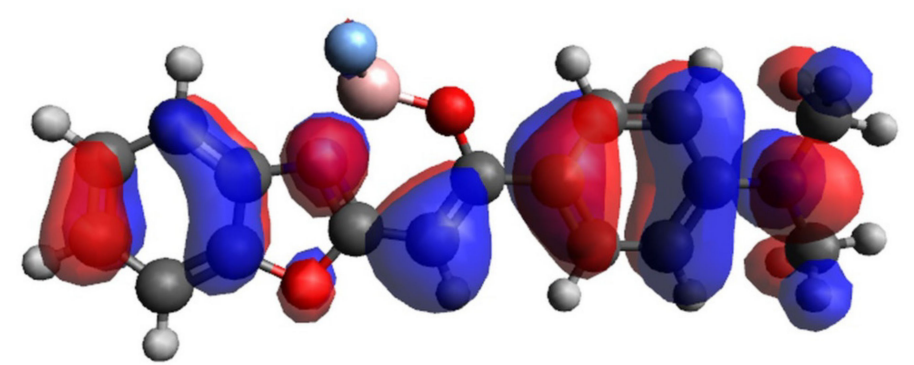

(a)

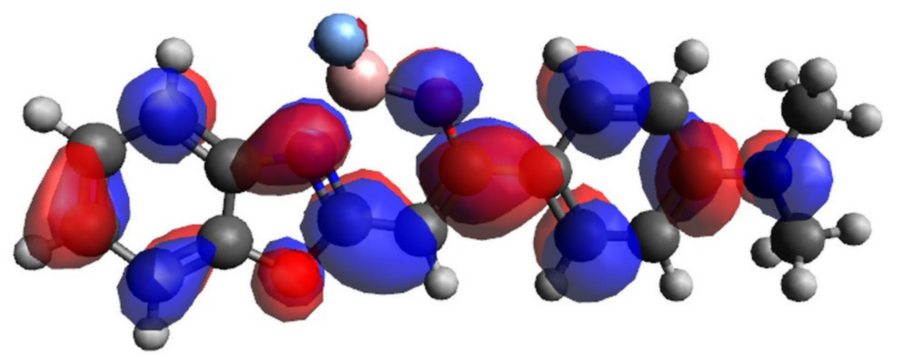

(b)

Figure 6. Distribution of HOMO (a) and LUMO (b) orbitals for 2-(4-dimethylamino)benzoylbenzoxazole difluoroborane (1).

\subsection{Vibrational Analysis}

Vibrational spectroscopy is used extensively for the study of molecular conformations, identification of functional groups and reaction kinetics, etc. Spectroscopy FT-IR and quantum chemical 
calculations using the B3LYP functional and 6-311++G(d,p) basis set have been employed to study the structure of the title compounds. Substituted 2-phenacylbenzoxazoles $\mathbf{1 b}$ - $\mathbf{8 b}$ (starting compounds that were converted to $\mathrm{BF}_{2}$ complexes) exist in two tautomeric forms, the ketimine form (K) and enolimine form $(\mathbf{O})$, through keto-enol tautomerization. A strong band observed in the FT-IR spectrum at around $1660 \mathrm{~cm}^{-1}$ was assigned to the $\mathrm{C}=\mathrm{O}$ stretching vibration of ketimine tautomer. The free hydroxyl group absorbs strongly in the region $3700-3584 \mathrm{~cm}^{-1}$, whereas the existence of intramolecular hydrogen bond formation can lower the $\mathrm{O}-\mathrm{H}$ stretching frequency in the range $3500-3200 \mathrm{~cm}^{-1}$ with an increase in intensity and breadth [22]. In the present study, a strong band observed at about $3380 \mathrm{~cm}^{-1}$ in FT-IR spectrum was assigned to O-H stretching vibration. The observed FT-IR spectrum of 2-(4-dimethylamino)benzoylbenzoxazole (1b), where the intensity was plotted against the vibrational wavenumber, is shown in Figure 7.

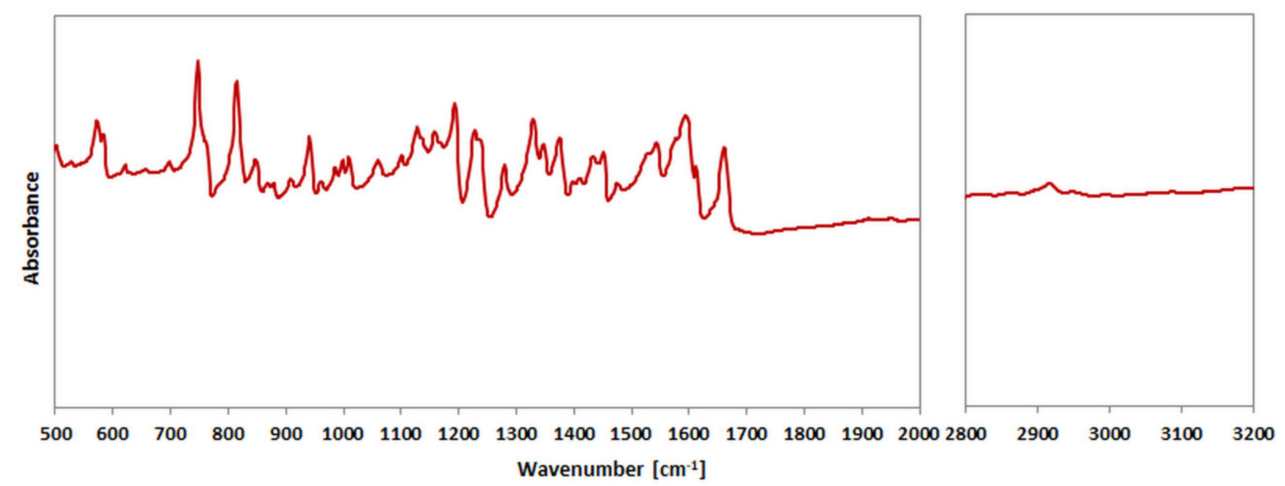

Figure 7. The observed IR absorption spectra of 2-(4-dimethylamino)benzoylbenzoxazole (1b) in the region $500-2000 \mathrm{~cm}^{-1}$ and $2800-3200 \mathrm{~cm}^{-1}$.

For the substituted 2-phenacylbenzoxazole difluoroboranes 1-8, no $\mathrm{O}-\mathrm{H}$ and $\mathrm{C}=\mathrm{O}$ vibrations could be observed in the FT-IR spectra. The theoretical spectrogram for the FT-IR spectrum of 2-(4-dimethylamino)benzoylbenzoxazole difluoroborane (1) was also constructed and compared with the experimental spectrum. The computed vibrational frequencies of this molecule were found in good agreement with experimental results. To improve the numerical agreement, the linear scaling method as given by Yoshida et al. [23] has been used. In this, the calculated harmonic vibrational wavenumbers have been scaled by the formula $\left(v_{\mathrm{obs}} / v_{\mathrm{cal}}=\left(1.0087-0.000016 \times v_{\mathrm{cal}}\right) \mathrm{cm}^{-1}\right)$ to facilitate a better agreement with the observed values. The value of the correlation coefficient was found to be $\mathrm{R}^{2}=0.9997$, which shows good agreement of the simulated wavenumbers with the observed one for the molecule of 2-(4-dimethylamino)benzoylbenzoxazole difluoroborane (1). The comparison of the experimental and simulated IR spectrum is presented in Figure 8.

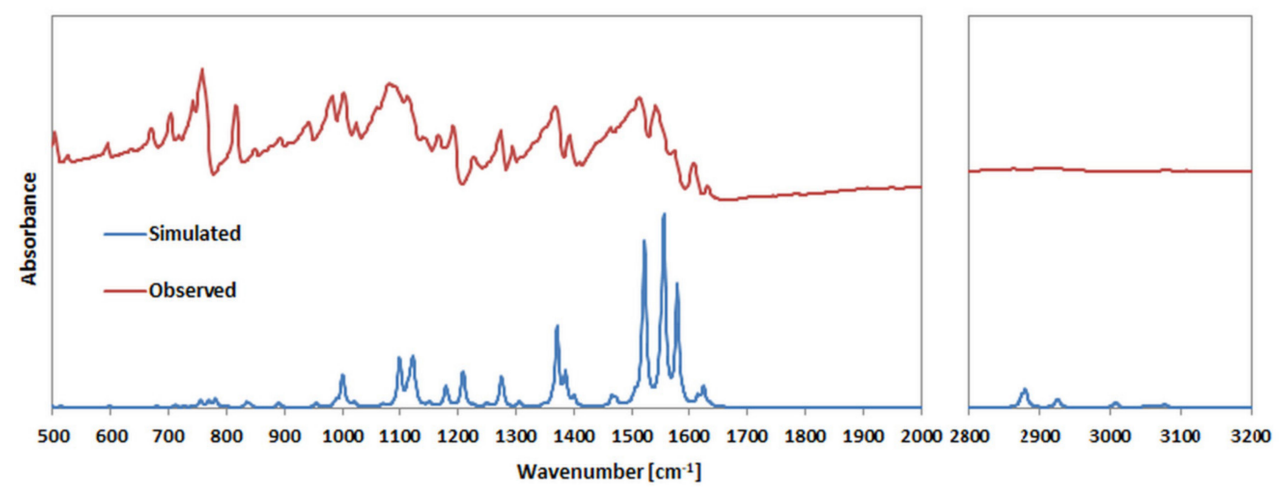

Figure 8. Comparison of the observed with simulated (scaled) IR absorption spectra of 2-(4-dimethylamino)benzoylbenzoxazole difluoroborane (1) in the region 500-2000 $\mathrm{cm}^{-1}$ and $2800-3200 \mathrm{~cm}^{-1}$. 


\section{Experimental}

\subsection{Materials}

All reagents and solvents were purchased from Sigma-Aldrich (Poznań, Poland) and used without further purification. The highest $(\geq 99 \%)$ purity of all used chemicals was required for spectroscopic studies.

\subsection{Synthesis}

The compounds were obtained from 2-phenacylbenzoxazoles $\mathbf{1 b}-\mathbf{8 b}$ (Scheme 2) as described earlier [15]. The typical procedure was as follows: $\mathrm{BF}_{3}$ etherate (three equivalents) was added to the magnetically stirred solution (nitrogen atmosphere) of substituted 2-phenacylbenzoxazole ( $1 \mathrm{~g})$ in dry chloroform (15-20 mL) and $N$-ethyldiisopropylamine (three equivalents). Then the solution was stirred overnight at room temperature, and concentrated $\mathrm{Na}_{2} \mathrm{CO}_{3}$ water solution $(20 \mathrm{~mL})$ was added slowly to the mixture. The organic fraction was separated, the water layer extracted with chloroform (two times using ca. 20-30 mL), dried $\left(\mathrm{Na}_{2} \mathrm{SO}_{4}\right)$ and evaporated under reduced pressure. Residual solids were purified by flash chromatography $\left(\mathrm{SiO}_{2}\right)$ using DCM as an eluent.

Elemental Analysis Is as Follows

2-(4-Dimethylamino)benzoylbenzoxazole Difluoroborane (1) Orange solid, yield 41\%, m.p. 298-300 ${ }^{\circ} \mathrm{C}$. ${ }^{1} \mathrm{H}-\mathrm{NMR}\left(\mathrm{CDCl}_{3}\right.$ from TMS) $\delta(\mathrm{ppm}): 7.96\left(\mathrm{~d}, 2 \mathrm{H},{ }^{3} \mathrm{~J}_{\mathrm{H}, \mathrm{H}}=9.12 \mathrm{~Hz}\right), 7.85\left(\mathrm{~d}, 1 \mathrm{H},{ }^{3} \mathrm{~J}_{\mathrm{H}, \mathrm{H}}=7.36 \mathrm{~Hz}\right)$, $7.61\left(\mathrm{~d}, 1 \mathrm{H},{ }^{3} J_{\mathrm{H}, \mathrm{H}}=7.64 \mathrm{~Hz}\right), 7.50(\mathrm{~m}, 2 \mathrm{H}), 6.89(\mathrm{~s}, 1 \mathrm{H}), 6.81\left(\mathrm{~d}, 2 \mathrm{H},{ }^{3} \mathrm{~J}_{\mathrm{H}, \mathrm{H}}=9.16 \mathrm{~Hz}\right), 3.07(\mathrm{~s}, 6 \mathrm{H})$. ${ }^{11} \mathrm{~B}-\mathrm{NMR}\left(\mathrm{CDCl}_{3}\right.$ from $\left.\mathrm{BF}_{3} \cdot \mathrm{Et}_{2} \mathrm{O}\right) \delta(\mathrm{ppm}): 1.79,(\mathrm{t}) .{ }^{13} \mathrm{C}-\mathrm{NMR} \delta(\mathrm{ppm}): 172.1,153.7,152.4,148.2$, 130.6, 129.6, 127.0, 125.9, 119.1, 114.2, 112.1, 111.8, 77.7, ca. 40.61-39.35 (overlapped with solvent). ${ }^{15} \mathrm{~N}-\mathrm{NMR}\left(\mathrm{CDCl}_{3}\right.$ from $\left.\mathrm{MeNO}_{2}\right) \delta(\mathrm{ppm}):-313.97 .{ }^{19} \mathrm{~F}-\mathrm{NMR}\left(\mathrm{CDCl}_{3}\right.$ from $\left.\mathrm{CFCl}_{3}\right) \delta(\mathrm{ppm}):-134.64$. $\mathrm{C}_{17} \mathrm{H}_{15} \mathrm{BF}_{2} \mathrm{~N}_{2} \mathrm{O}_{2}$, Calcd. C, 62.23; $\mathrm{H}, 4.61 ; \mathrm{N}, 8.54$. Found $\mathrm{C}, 62.14 ; \mathrm{H}, 4.64 ; \mathrm{N}, 8.39$.

2-(4-Methoxy)benzoylbenzoxazole Difluoroborane (2) Yellow solid, yield 39\%, m.p. 242-243 ${ }^{\circ} \mathrm{C}$ (251-253 $\left.{ }^{\circ} \mathrm{C}[9]\right) .{ }^{1} \mathrm{H}-\mathrm{NMR}\left(\mathrm{CDCl}_{3}\right.$ from TMS) $\delta$ (ppm): $7.98(\mathrm{~m}, 2 \mathrm{H}), 7.78\left(\mathrm{~d}, 1 \mathrm{H},{ }^{3} J_{\mathrm{H}, \mathrm{H}}=7.84 \mathrm{~Hz}\right), 7.55$ $\left(\mathrm{d}, 1 \mathrm{H},{ }^{3} \mathrm{~J}_{\mathrm{H}, \mathrm{H}}=8.16 \mathrm{~Hz}\right), 7.47(\mathrm{~m}, 1 \mathrm{H}), 7.40(\mathrm{~m}, 1 \mathrm{H}), 6.98(\mathrm{~m}, 2 \mathrm{H}), 6.37(\mathrm{~s}, 1 \mathrm{H}), 3.89(\mathrm{~s}, 3 \mathrm{H}) .{ }^{11} \mathrm{~B}-\mathrm{NMR}$ $\left(\mathrm{CDCl}_{3}\right.$ from $\left.\mathrm{BF}_{3} \cdot \mathrm{Et}_{2} \mathrm{O}\right) \delta(\mathrm{ppm}): 1.80,(\mathrm{t}) .{ }^{13} \mathrm{C}-\mathrm{NMR} \delta(\mathrm{ppm}): 172.2164 .9,163.3,148.1,130.6,129.3$, 126.6 125.6, 115.2, 114.1, 111.0, 78.8, 55.5. ${ }^{15} \mathrm{~N}-\mathrm{NMR}\left(\mathrm{CDCl}_{3}\right.$ from $\left.\mathrm{MeNO}_{2}\right) \delta$ (ppm): -215.72. ${ }^{19} \mathrm{~F}-\mathrm{NMR}$ $\left(\mathrm{CDCl}_{3}\right.$ from $\left.\mathrm{CFCl}_{3}\right) \delta(\mathrm{ppm}):-135.59 . \mathrm{C}_{16} \mathrm{H}_{12} \mathrm{BF}_{2} \mathrm{NO}_{3}$, Calcd. C, 60.99; $\mathrm{H}, 3.84 ; \mathrm{N}, 4.45$. Found $\mathrm{C}$, $60.69 ; \mathrm{H}, 3.99 ; \mathrm{N}, 4.60$.

2-(4-Methyl)benzoylbenzoxazole Difluoroborane (3) Yellow solid, yield 47\%, m.p. $256-258^{\circ} \mathrm{C} .{ }^{1} \mathrm{H}-\mathrm{NMR}$ $\left(\mathrm{CDCl}_{3}\right.$ from TMS) $\delta(\mathrm{ppm}): 7.91(\mathrm{~m}, 2 \mathrm{H}), 7.80\left(\mathrm{~d}, 1 \mathrm{H},{ }^{3} \mathrm{~J}_{\mathrm{H}, \mathrm{H}}=8.36 \mathrm{~Hz}\right), 7.57(\mathrm{~m}, 1 \mathrm{H}), 7.48(\mathrm{~m}, 1 \mathrm{H})$, $7.40(\mathrm{~m}, 1 \mathrm{H}), 7.41(\mathrm{~m}, 1 \mathrm{H}), 7.29\left(\mathrm{~d}, 2 \mathrm{H},{ }^{3} \mathrm{~J}_{\mathrm{H}, \mathrm{H}}=8.00 \mathrm{~Hz}\right), 6.44(\mathrm{~s}, 1 \mathrm{H}) 2.44(\mathrm{~s}, 3 \mathrm{H}) .{ }^{11} \mathrm{~B}-\mathrm{NMR}\left(\mathrm{CDCl}_{3}\right.$ from $\left.\mathrm{BF}_{3} \cdot \mathrm{Et}_{2} \mathrm{O}\right) \delta(\mathrm{ppm}): 1.84,(\mathrm{t}) .{ }^{13} \mathrm{C}-\mathrm{NMR} \delta$ (ppm): 172.6, 164.9, 148.2, 143.5, 130.6, 129.5, 127.3, 126.7, 125.8, 115.4, 111.1, 79.7, 21.7. ${ }^{15} \mathrm{~N}-\mathrm{NMR}\left(\mathrm{CDCl}_{3}\right.$ from $\left.\mathrm{MeNO}_{2}\right) \delta(\mathrm{ppm}):-215.01 .{ }^{19} \mathrm{~F}-\mathrm{NMR}\left(\mathrm{CDCl}_{3}\right.$ from $\left.\mathrm{CFCl}_{3}\right) \delta$ (ppm): -135.34. $\mathrm{C}_{16} \mathrm{H}_{12} \mathrm{BF}_{2} \mathrm{NO}_{2}$, Calcd. C, 64.25; H, 4.04; N, 4.68. Found C, 64.35; $\mathrm{H}, 3.94 ; \mathrm{N}, 4.68$.

2-(3-Methyl)benzoylbenzoxazole Difluoroborane (4) Yellow solid, yield 48\%, m.p. $230-231{ }^{\circ} \mathrm{C} .{ }^{1} \mathrm{H}-\mathrm{NMR}$ $\left(\mathrm{CDCl}_{3}\right.$ from TMS) $\delta(\mathrm{ppm}): 7.85(\mathrm{~s}, 1 \mathrm{H}), 7.76(\mathrm{~m}, 2 \mathrm{H}), 7.57(\mathrm{~m}, 1 \mathrm{H}), 7.49(\mathrm{~m}, 1 \mathrm{H}), 7.49(\mathrm{~m}, 1 \mathrm{H}), 7.42$ $(\mathrm{m}, 1 \mathrm{H}), 7.37(\mathrm{~m}, 2 \mathrm{H}), 6.47(\mathrm{~s}, 1 \mathrm{H}) 2.44(\mathrm{~s}, 3 \mathrm{H}) .{ }^{11} \mathrm{~B}-\mathrm{NMR}\left(\mathrm{CDCl}_{3}\right.$ from $\left.\mathrm{BF}_{3} \cdot \mathrm{Et}_{2} \mathrm{O}\right) \delta(\mathrm{ppm}): 1.86,(\mathrm{t})$. ${ }^{13} \mathrm{C}-\mathrm{NMR} \delta$ (ppm): 172.7, 164.8, 148.2, 138.6, 133.4, 133.1, 130.5, 128.6, 127.9, 126.7, 125.9, 124.4, 115.4, 111.1, 80.3, 21.4. ${ }^{15} \mathrm{~N}-\mathrm{NMR}\left(\mathrm{DMSO}-d_{6}\right.$ from $\left.\mathrm{MeNO}_{2}\right) \delta(\mathrm{ppm}):-214.18 .{ }^{19} \mathrm{~F}-\mathrm{NMR}\left(\mathrm{CDCl}_{3}\right.$ from $\left.\mathrm{CFCl}_{3}\right)$ $\delta$ (ppm): -135.14. $\mathrm{C}_{16} \mathrm{H}_{12} \mathrm{BF}_{2} \mathrm{NO}_{2}$, Calcd. C, 64.25; $\mathrm{H}, 4.04 ; \mathrm{N}, 4.68$. Found $\mathrm{C}, 63.92 ; \mathrm{H}, 4.1 ; \mathrm{N}, 4.85$.

2-Benzoylbenzoxazole Difluoroborane (5) Yellowish-green solid, yield 38\%, m.p. 239.2-240.8 ${ }^{\circ} \mathrm{C}$ (244-246 $\left.{ }^{\circ} \mathrm{C}[9]\right) . ~{ }^{1} \mathrm{H}-\mathrm{NMR}\left(\mathrm{CDCl}_{3}\right.$ from TMS) $\delta: 8.02(\mathrm{~m}, 2 \mathrm{H}), 7.82(\mathrm{~m}, 1 \mathrm{H}), 7.57(\mathrm{~m}, 2 \mathrm{H}) 7.51(\mathrm{~m}, 2 \mathrm{H})$, $7.45(\mathrm{~m}, 2 \mathrm{H}), 6.49(\mathrm{~s}, 1 \mathrm{H}) .{ }^{11} \mathrm{~B}-\mathrm{NMR}\left(\mathrm{CDCl}_{3}\right.$ from $\left.\mathrm{BF}_{3} \cdot \mathrm{Et}_{2} \mathrm{O}\right) \delta: 1.85$, (t). ${ }^{13} \mathrm{C}-\mathrm{NMR} \delta: 170.8,165.1$, $148.5,133.1,130.1,129.5,127.5,126.9,126.4,114.9,112.5,82.1 .{ }^{15} \mathrm{~N}-\mathrm{NMR}\left(\mathrm{CDCl}_{3}\right.$ from $\left.\mathrm{MeNO}_{2}\right)$ 


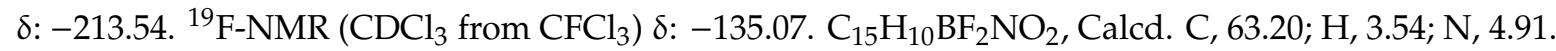
Found C, 63.25; H, 3.49; N, 4.83 .

2-(3-Methoxy)benzoylbenzoxazole Difluoroborane (6) Yellow solid, yield $42 \%$, m.p. $\quad 218-220{ }^{\circ} \mathrm{C}$ (235-237 $\left.{ }^{\circ} \mathrm{C}[9]\right) .{ }^{1} \mathrm{H}-\mathrm{NMR}\left(\mathrm{CDCl}_{3}\right.$ from TMS) $\delta(\mathrm{ppm}): 7.82\left(\mathrm{~d}, 1 \mathrm{H},{ }^{3} J_{\mathrm{H}, \mathrm{H}}=7.84 \mathrm{~Hz}\right), 7.56(\mathrm{~m}, 3 \mathrm{H})$, $7.49(\mathrm{~m}, 1 \mathrm{H}), 7.44(\mathrm{~m}, 1 \mathrm{H}), 7.40(\mathrm{~m}, 1 \mathrm{H}), 7.09(\mathrm{~m}, 1 \mathrm{H}), 6.47(\mathrm{~s}, 1 \mathrm{H}) 3.9(\mathrm{~s}, 3 \mathrm{H}) .{ }^{11} \mathrm{~B}-\mathrm{NMR}\left(\mathrm{CDCl}_{3}\right.$ from $\left.\mathrm{BF}_{3} \cdot \mathrm{Et}_{2} \mathrm{O}\right) \delta(\mathrm{ppm}): 1.84,(\mathrm{t}) .{ }^{13} \mathrm{C}-\mathrm{NMR} \delta$ (ppm): 172.3, 164.7, 159.9, 148.2, 134.6, 130.5, 129.7, 126.8 , 126.0, 119.6, 118.9, 115.5, 112.0, 111.2, 80.7, 55.6. ${ }^{15} \mathrm{~N}-\mathrm{NMR}\left(\mathrm{CDCl}_{3}\right.$ from $\left.\mathrm{MeNO}_{2}\right) \delta(\mathrm{ppm}):-213.97$. ${ }^{19} \mathrm{~F}-\mathrm{NMR}\left(\mathrm{CDCl}_{3}\right.$ from $\left.\mathrm{CFCl}_{3}\right) \delta(\mathrm{ppm}):-134.98 . \mathrm{C}_{16} \mathrm{H}_{12} \mathrm{BF}_{2} \mathrm{NO}_{3}$, Calcd. C, 60.99; $\mathrm{H}, 3.84 ; \mathrm{N}, 4.45$. Found C, 60.72; H, 4.01; N, 4.95 .

2-(4-Chloro)benzoylbenzoxazole Difluoroborane (7) Yellow solid, yield 37\%, m.p. $233-235{ }^{\circ} \mathrm{C}$ $\left(250{ }^{\circ} \mathrm{C}[10]\right) .{ }^{1} \mathrm{H}-\mathrm{NMR}\left(\mathrm{CDCl}_{3}\right.$ from TMS $) \delta(\mathrm{ppm}): 7.94(\mathrm{~m}, 2 \mathrm{H}), 7.82\left(\mathrm{~d}, 1 \mathrm{H},{ }^{3} J_{\mathrm{H}, \mathrm{H}}=7.84 \mathrm{~Hz}\right)$, $7.58(\mathrm{~m}, 1 \mathrm{H}), 7.51(\mathrm{~m}, 1 \mathrm{H}), 7.47(\mathrm{~m}, 2 \mathrm{H}), 7.44(\mathrm{~m}, 1 \mathrm{H}), 6.45(\mathrm{~s}, 1 \mathrm{H}) .{ }^{11} \mathrm{~B}-\mathrm{NMR}\left(\mathrm{CDCl}_{3}\right.$ from BF$\left._{3} \cdot \mathrm{Et}_{2} \mathrm{O}\right) \delta$ (ppm): 1.81, (t). ${ }^{13} \mathrm{C}-\mathrm{NMR} \delta$ (ppm): 171.0, 164.5, 148.2, 138.8, 131.6, 130.4, 129.1, 128.5, 126.9, 126.2, 115.5, 111.2, 80.6. ${ }^{15} \mathrm{~N}-\mathrm{NMR}\left(\mathrm{CDCl}_{3}\right.$ from $\left.\mathrm{MeNO}_{2}\right) \delta(\mathrm{ppm}):-213.00 .{ }^{19} \mathrm{~F}-\mathrm{NMR}\left(\mathrm{CDCl}_{3}\right.$ from $\left.\mathrm{CFCl}_{3}\right) \delta$ (ppm): -134.98. $\mathrm{C}_{15} \mathrm{H}_{9} \mathrm{BF}_{2} \mathrm{NO}_{2}$, Calcd. $\mathrm{C}, 56.39 ; \mathrm{H}, 2.84 ; \mathrm{N}, 4.38$. Found $\mathrm{C}, 56.51 ; \mathrm{H}, 2.75 ; \mathrm{N}, 4.41$.

2-(3-Chloro)benzoylbenzoxazole Difluoroborane (8) Yellow solid, yield $34 \%$, m.p. $228-230{ }^{\circ} \mathrm{C}$. ${ }^{1} \mathrm{H}-\mathrm{NMR}\left(\mathrm{CDCl}_{3}\right.$ from TMS) $\delta(\mathrm{ppm}): 8.00(\mathrm{t}, 1 \mathrm{H}), 7.88(\mathrm{~m}, 1 \mathrm{H}), 7.83\left(\mathrm{~d}, 1 \mathrm{H},{ }^{3} \mathrm{~J}_{\mathrm{H}, \mathrm{H}}=7.84 \mathrm{~Hz}\right)$, $7.60(\mathrm{~m}, 1 \mathrm{H}), 7.52(\mathrm{~m}, 2 \mathrm{H}), 7.45(\mathrm{~m}, 2 \mathrm{H}), 6.48(\mathrm{~s}, 1 \mathrm{H}) .{ }^{11} \mathrm{~B}-\mathrm{NMR}\left(\mathrm{CDCl}_{3}\right.$ from $\left.\mathrm{BF}_{3} \cdot \mathrm{Et}_{2} \mathrm{O}\right) \delta(\mathrm{ppm}): 1.81,(\mathrm{t})$. ${ }^{13} \mathrm{C}-\mathrm{NMR} \delta$ (ppm): 170.6, 164.4, 148.3, 135.1, 135.0, 132.4, 130.4, 130.1, 127.3, 126.9, 126.3, 125.3, 115.6, 111.3, 81.2. ${ }^{15} \mathrm{~N}-\mathrm{NMR}\left(\mathrm{CDCl}_{3}\right.$ from $\left.\mathrm{MeNO}_{2}\right) \delta$ (ppm): $-212.43 .{ }^{19} \mathrm{~F}-\mathrm{NMR}\left(\mathrm{CDCl}_{3}\right.$ from $\left.\mathrm{CFCl}_{3}\right) \delta$ (ppm): -134.78. $\mathrm{C}_{15} \mathrm{H}_{9} \mathrm{BF}_{2} \mathrm{NO}_{2}$, Calcd. $\mathrm{C}, 56.39 ; \mathrm{H}, 2.84 ; \mathrm{N}, 4.38$. Found $\mathrm{C}, 56.26 ; \mathrm{H}, 2.81 ; \mathrm{N}, 4.54$.

\subsection{Measurements}

The ${ }^{1} \mathrm{H}-\mathrm{NMR}$ spectra were recorded using an Ascend III spectrometer operating at $400 \mathrm{MHz}$, Bruker (Bydgoszcz, Poland). Chloroform was used as a solvent and tetramethylsilane (TMS) as the internal standard. Chemical shifts $(\delta)$ were reported in ppm relative to TMS and coupling constants $(J)$ in $\mathrm{Hz}$.

The elemental analysis was made with a Vario MACRO 11.45-0000, Elemental Analyser System $\mathrm{GmbH}$, operating with the VARIOEL software (version 5.14.4.22).

The melting point was measured on the Melting Point M-565 Apparatus (Buchi) with the measuring speed $5^{\circ} \mathrm{C} / \mathrm{min}$.

The absorption and emission spectra were measured at room temperature in a quartz cuvette $(1 \mathrm{~cm})$ using an Agilent Technology UV-Vis Cary 60 Spectrophotometer and a Hitachi F-7000 Spectrofluorometer, respectively.

The fluorescence quantum yields for the compounds in chloroform were determined as follows, the fluorescence spectrum of diluted $(\mathrm{A} \approx 0.1)$ boranes solution was recorded by excitation at the absorption band maximum of the reference. Diluted 9,10-diphenylanthracene in cyclohexane $(\phi=0.93)$ [24] was used as reference. The fluorescence spectrum of 9,10-diphenylanthracene was obtained by excitation at its absorption peak at $355 \mathrm{~nm}$. The quantum yield of the tested compounds $\left(\phi_{\text {dye }}\right)$ was calculated using the following equation [25]:

$$
\phi_{\text {dye }}=\phi_{\text {ref }} \cdot \frac{I_{\text {dye }}}{I_{\text {ref }}} \frac{A_{\text {ref }}}{A_{\text {dye }}} \cdot \frac{n_{\text {dye }}^{2}}{n_{r e f}^{2}}
$$

where $\phi_{\text {ref }}$ is the fluorescence quantum yield of the reference sample (9,10-diphenylanthracene) in cyclohexane, $A_{\text {dye }}$ and $A_{\text {ref }}$ are the absorbance of the dye and reference samples at the excitation wavelengths $(355 \mathrm{~nm}), I_{\text {dye }}$ and $I_{\text {ref }}$ are the integrated emission intensity for the dyes and references sample, $n_{\text {dye }}$ and $n_{\text {ref }}$ are the refractive indices of the solvents used for the dyes and reference, respectively. Coumarine 153 in cyclohexane $\left(\phi=0.90\right.$ [26]; $\lambda_{e x}=393 \mathrm{~nm}$ ) was used as reference standard for compound carrying $-\mathrm{NMe}_{2}$ group.

Infrared spectra have been recorded in the region $360-7000 \mathrm{~cm}^{-1}$ on a Bruker Alpha FT-IR spectrometer with a spectral resolution of $2 \mathrm{~cm}^{-1}$ using the ATR (attenuated total reflectance) method. 
The geometry optimization, vibrational spectra, and the HOMO and LUMO energies were calculated based on density functional theory with the use of B3LYP [27-29] functional and 6-311++G(d,p) basis set [30,31]. All calculations were carried out using Gaussian 09 software [32]. The analysis of the frontier orbitals and IR spectra including extraction of frequencies and a visual presentation of the vibrational modes and orbitals was realized with the use of Avogadro 1.2.0 application [33].

\section{Conclusions}

The indicated aims were achieved through a synthesis of a series of 2-phenacylbenzoxazole difluoroboranes substituted by a weaker electron-withdrawing $(\mathrm{Cl})$ and electron-releasing (4-Me, 4-OMe, and $4-\mathrm{NMe}_{2}$ ) substituents. Complexes have been identified based on a magnetic atomic nucleus ${ }^{1} \mathrm{H},{ }^{11} \mathrm{~B},{ }^{13} \mathrm{C},{ }^{15} \mathrm{~N}$, and ${ }^{19} \mathrm{~F}$ isotope resonance spectra. ${ }^{15} \mathrm{~N}-\mathrm{NMR}$ shifts correlate with the substituent character of the phenyl ring with $\mathrm{R}^{2}=0.91$. The spectral data show that the absorption and fluorescence properties of 2-phenacylbenzoxazole difluoroboranes 1-8 depend on the character of the substituent. The experimental results indicate the positive solvatochromism of studied compounds with increasing solvent polarity. Among all derivatives, only 2-(4-dimethylamino)-benzoylbenzoxazole difluoroborane 1 (the $\mathrm{NMe}_{2}$ group was the strongest electron donor in the series) presented strong and relatively red-shifted fluorescence in the chloroform. Other complexes hardly demonstrated any fluorescence, indicating that probably only benzoxazole-boron complexes with strongly electron-releasing groups like amino groups could be attractive for their use as new fluorescent molecules for future applications in bio-labeling, medicine, or fluorescence microscopy, and they might be alternative or supplementary to popular BODIPY dyes. Furthermore, the study using these compounds as photosensitizers in the photopolymerization process is still in progress.

Supplementary Materials: The following are available online for related NMR spectra.

Author Contributions: Conceptualization, Methodology, investigation, writing-review, A.S.; performed DFT calculations, P.C. All authors have read and agreed to the published version of the manuscript.

Funding: This research was supported in part by PLGrid Infrastructure.

Conflicts of Interest: The authors declare no conflict of interest.

\section{References}

1. Lu, H.; Mack, J.; Yang, Y.; Shen, Z. Structural modification strategies for the rational design of red/NIR region BODIPYs. Chem. Soc. Rev. 2014, 43, 4778-4823. [CrossRef]

2. Jean-Gérard, L.; Vasseur, W.; Scherninski, F; Andrioletti, B. Recent advances in the synthesis of [a]-benzo-fused BODIPY fluorophores. Chem. Commun. 2018, 54, 12914-12929. [CrossRef]

3. Zhao, J.; Xu, K.; Yang, W.; Wang, Z.; Zhong, F. The triplet excited state of Bodipy: Formation, modulation and application. Chem. Soc. Rev. 2015, 44, 8904-8939. [CrossRef] [PubMed]

4. Sansalone, L.; Tang, S.; Garcia-Amoros, J.; Zhang, Y.; Nonell, S.; Baker, J.D.; Captain, B.; Raymo, F.M. A photoactivatable far-red/near-infrared BODIPY to monitor cellular dynamics in vivo. ACS Sens. 2018, 3, 1347-1353. [CrossRef] [PubMed]

5. Boens, N.; Leen, V.; Dehaen, W. Fluorescent indicators based on BODIPY. Chem. Soc. Rev. 2012, 41, 1130-1172. [CrossRef] [PubMed]

6. $\mathrm{Ni}, \mathrm{Y}$;; $\mathrm{Wu}, \mathrm{J}$. Far-red and near infrared BODIPY dyes: Synthesis and applications for fluorescent $\mathrm{pH}$ probes and bio-imaging. Org. Biomol. Chem. 2014, 12, 3774-3791. [CrossRef] [PubMed]

7. Telitel, S.; Blanchard, N.; Schweizer, S.; Morlet-Savary, F.; Graff, B.; Fouassier, J.-P.; Lalevee, J. BODIPY derivatives and boranil as new photoinitiating systems of cationic polymerization exhibiting a tunable absorption in the 400-600 nm spectral range. Polymer 2013, 54, 2071-2076. [CrossRef]

8. Telitel, S.; Lalevee, J.; Blanchard, N.; Kavalli, T.; Tehfe, M.-A.; Schweizer, S.; Morlet-Savary, F.; Graff, B.; Fouassier, J.-P. Photopolymerization of cationic monomers and acrylate/divinylether blends under visible light using pyrromethene dyes. Macromolecules 2012, 45, 6864-6868. [CrossRef] 
9. Zhang, Z.; Wu, Z.; Sun, J.; Xue, P.; Lu, R. Multi-color solid-state emission of $\beta$-iminoenolate boron complexes tuned by methoxyl groups: Aggregation-induced emission and mechanofluorochromism. RSC Adv. 2016, 6, 43755-43766. [CrossRef]

10. Zhao, J.; Peng, J.; Chen, P.; Wang, H.; Xue, P.; Lu, R. Mechanofluorochromism of difluoroboron $\beta$-ketoiminate boron complexes functionalized with benzoxazole and benzothiazole. Dyes Pigm. 2018, 149, 276-283. [CrossRef]

11. Grabarz, A.M.; Jedrzejewska, B.; Skotnicka, A.; Murugan, N.A.; Patalas, F.; Bartkowiak, W.; Jacquemin, D.; Ośmiałowski, B. The impact of the heteroatom in a five-membered ring on the photophysical properties of difluoroborates. Dyes Pigm. 2019, 170, 1074812. [CrossRef]

12. Zakrzewska, A.; Zaleśny, R.; Kolehmainen, E.; Ośmiałowski, B.; Jędrzejewska, B.; Ågren, H.; Pietrzak, M. Substituent effects on the photophysical properties of fluorescent 2-benzoylmethylenequinoline difluoroboranes: A combined experimental and quantum chemical study. Dyes Pigm. 2013, 99, 957-965. [CrossRef]

13. Ośmiałowski, B.; Zakrzewska, A.; Jędrzejewska, B.; Grabarz, A.M.; Zaleśny, R.; Bartkowiak, W.; Kolehmainen, E. Influence of substituent and benzoannulation on photophysical properties of 1-benzoylmethyleneisoquinoline difluoroborates. J. Org. Chem. 2015, 80, 2072-2080. [CrossRef] [PubMed]

14. Dzvinchuk, I.B.; Lozinskii, M.O.; Vypirailenko, A.V. C-Mono- and dibenzoylation of 2-methylbenzimidazole with use of benzoyl chloride. Zh. Org. Khim. 1994, 30, 909-914.

15. Skotnicka, A.; Kolehmainen, E.; Czeleń, P.; Valkonen, A.; Gawinecki, R. Synthesis and structural characterization of substituted 2-phenacylbenzoxazoles. Int. J. Mol. Sci. 2013, 14, 4444-4460. [CrossRef]

16. Kubota, Y.; Tanaka, S.; Funabiki, K.; Matsui, M. Synthesis and fluorescence properties of thiazole-boron complexes bearing a $\beta$-ketoiminate ligand. Org. Lett. 2012, 14, 4682-4685. [CrossRef]

17. Hansch, C.; Leo, A.; Taft, W. A survey of Hammett substituent constants and resonance and field parameters. Chem. Rev. 1991, 91, 165-195. [CrossRef]

18. Xu, S.; Evans, R.E.; Liu, T.; Zhang, G.; Demas, J.N.; Trindle, C.O.; Frser, C.L. Aromatic difluoroboron $\beta$-diketonate complexes: Effects of $\pi$-conjugation and media on optical properties. Inorg. Chem. 2013, 52, 3597-3610. [CrossRef]

19. Patil, R.S.; Patil, A.S.; Patil, V.S.; Jirimali, H.D.; Mahulikar, P.P. Synthesis, photophysical, solvatochromic and DFT studies of (Z)-2-(2-Phenyl-4H-benzo[4,5]thiazolo[3,2-a]pyrimidin-4-ylidene)acetonitrile derivatives. J. Lumin. 2019, 210, 303-310. [CrossRef]

20. Chitnis, D.; Thejokalyani, N.; Dhoble, S.J. Exploration of spectroscopic properties of solvated tris(thenoyltrifluoroacetonate)(2,2'-bipyridine)europium(III)red hybrid organic complex for solution processed OLEDs and displays. J. Lumin. 2017, 185, 61-71. [CrossRef]

21. Vennila, P.; Govindaraju, M.; Venkatesh, G.; Kamal, C. Molecular structure, vibrational spectral assignments (FT-IR and FT-RAMAN), NMR, NBO, HOMO-LUMO and NLO properties of O-methoxybenzaldehyde based on DFT calculations. J. Mol. Struct. 2016, 1111, 151-156. [CrossRef]

22. Silverstein, R.M.; Webster, F.X. Spectroscopic Identification of Organic Compound, 6th ed.; John Willey \& Sons: New York, NY, USA, 1998.

23. Yoshida, H.; Takeda, K.; Okamura, J.; Ehara, A.; Matsurra, H. A new approach to vibrational analysis of large molecules by density functional theory: Wavenumber-linear scaling method. J. Phys. Chem. A 2002, 106, 3580-3586. [CrossRef]

24. Meech, S.R.; Phillips, D. Photophysics of some common fluorescence standards. J. Photochem. 1983, 23, $193-217$. [CrossRef]

25. Brouwer, A.M. Standards for photoluminescence quantum yield measurements in solution (IUPAC Technical Report). Pure Appl. Chem. 2011, 83, 2213-2228. [CrossRef]

26. Jones, G., II; Jackson, W.R.; Choi, C.Y.; Bergmark, W.R. Solvent effects on emission yield and lifetime for coumarin laser dyes. Requirements for a rotatory decay mechanism. J. Phys. Chem. 1985, 89, 294-300. [CrossRef]

27. Lee, C.; Yang, W.; Parr, R.G. Development of the Colle-Salvetti correlation-energy formula into a functional of the electron density. Phys. Rev. B 1988, 37, 785-789. [CrossRef]

28. Becke, A.D. Density-functional thermochemistry. III. The role of exact exchange. J. Chem. Phys. 1993, 98, 5648-5652. [CrossRef] 
29. Ong, B.K.; Woon, K.L.; Ariffin, A. Evaluation of various density functionals for predicting the electrophosphorescent host HOMO, LUMO and triplet energies. Synth. Met. 2014, 195, 54-60. [CrossRef]

30. Petersson, G.A.; Bennett, A.; Tensfeldt, T.G.; Al-Laham, M.A.; Shirley, W.A.; Mantzaris, J. A complete basis set model chemistry. I. The total energies of closed-shell atoms and hydrides of the first-row elements. J. Chem. Phys. 1988, 89, 2193-2218. [CrossRef]

31. Petersson, G.A.; Al-Laham, M.A. A complete basis set model chemistry. II. Open-shell systems and the total energies of the first-row atoms. J. Chem. Phys. 1991, 94, 6081-6090. [CrossRef]

32. Frisch, D.J.; Trucks, M.J.; Schlegel, G.W.; Scuseria, H.B.; Robb, G.E.; Cheeseman, M.A.; Scalmani, J.R.; Barone, G.; Petersson, V.; Nakatsuji, G.A.; et al. Gaussian 09 (Revision A. 02); Gaussian, Inc.: Wallingford, CT, USA, 2016.

33. Hanwell, M.D.; Curtis, D.E.; Lonie, D.C.; Vandermeerschd, T.; Zurek, E.; Hutchison, G.R. Avogadro: An advanced semantic chemical editor, visualization, and analysis platform. J. Cheminform. 2012, 4, 17. [CrossRef] [PubMed]

Sample Availability: Samples of the compounds 1-8 are available from the authors.

Publisher's Note: MDPI stays neutral with regard to jurisdictional claims in published maps and institutional affiliations.

(C) 2020 by the authors. Licensee MDPI, Basel, Switzerland. This article is an open access article distributed under the terms and conditions of the Creative Commons Attribution (CC BY) license (http://creativecommons.org/licenses/by/4.0/). 